\title{
The Association Between Mother's Care Practices With Stunting Incident In Children Age 12-35 Months In Air Dingin Primary Health Center Padang 2018
}

\author{
Wahyu Zikria $^{1}$, Masrul $^{2}$, Lusiana El Sinta Bustami ${ }^{3}$ \\ ${ }^{1}$ Bachelor Of Midwifery Program FK UNAND, Jl. Niaga No. 56 Padang City, Indonesia \\ ${ }^{2}$ Department Of Nutrition Sciences FK UNAND, Jl. Perintis Kemerdekaan No. 94 Padang City, Indonesia \\ ${ }^{3}$ Bachelor Of Midwifery Program FK UNAND, Jl. Niaga No. 56 Padang City, Indonesia
}

\begin{tabular}{|c|}
\hline SUBMISSION TRACK \\
\hline $\begin{array}{l}\text { Recieved: } 29^{\text {th }} \text { June } 2018 \\
\text { Final Revision: } 10^{\text {th }} \text { July } 2018 \\
\text { Available Online: }\end{array}$ \\
\hline KEYWORDS \\
\hline $\begin{array}{l}\text { stunting, care practice for feeding, care } \\
\text { practice for hygiene, care practice for } \\
\text { health and care practice for psychosocial } \\
\text { stimulation }\end{array}$ \\
\hline CORRESPONDENCE \\
\hline
\end{tabular}

\section{INTRODUCTION}

Stunting (short body) is the long-term outcome of nutritional deficiency with height by age less than -2 SD (Standard Deviation)

\begin{abstract}
A B S T R A C T
Stunting is the long-term outcome of nutritional deficiency with height by age less than -2SD below the median length who affects to decreased cognitive and physical abilities in children. The aims of this study is to determine the association between mother's care practices with stunting incidennt in the children age 12-35 months in Air Dingin Primary Health Center Padang 2018.

This study was a quantitative study with cross sectional design conducted at Air Dingin health center from April 2018 to May 2018. There were 77 mothers with 12-35 month childrens became sample of this study. The mother as the respondent was interviewed directly with a questionnaire. While the stunting incident was measured by body height/age and interpreted by WHO-antro software. Data will analyzed in univariate and bivariate by using chisquare analysis $(\mathrm{p}<0,05)$.

The result of the study showed that $46,8 \%$ childrens suffered stunting. The result of chi-square analysis revealed $\mathrm{p}$-value between care practice for feeding $(\mathrm{p}=0,000)$, care practice for hygiene $(\mathrm{p}=0,000)$, care practice for health $(\mathrm{p}=0,000)$ and care practice for psychosocial stimulation $(\mathrm{p}=0,000)$.

There is an association between care practice for feeding, care practice for hygiene, care practice for health and care practice for psychosocial stimulation with stunting incident. It is expected that mothers to pay more attention to care practices provided to children so as to prevent the occurrence of stunting in children.
\end{abstract}

below the median length (WHO, 2010). Stunting is considered an irreversible growth disorder due to inadequate nutrition and the 
presence of recurrent infections during the first 1.000 days of life (UNICEF, 2013).

Globally, the prevalence of stunting in 2016 is 154.8 million or $22.9 \%$ in children under 5 years of age (UNICEF et al., 2017). If this trend continues, by 2025 it is projected that 127 million children under 5 will experience stunting (WHO, 2014).

By 2016 there are $38 \%$ of live stunting children in Africa. The number of stunting children in Africa has increased from 58.6 million stunting children by 2015 to 59 million stunting children by 2016 . Increased stunting prevalence occurs in North America from $2.1 \%$ in 2015 and to $2.3 \%$ by 2016 , as well as in the Ocenia region an increase in stunting prevalence from $38.2 \%$ in 2015 to $38.3 \%$ by 2016 (UNICEF et al., 2017).

The prevalence of stunting in Caribia dropped from $5.5 \%$ in 2015 to $5.3 \%$ in 2016 , as well as in Asia the prevalence of stunting decreased from $24.6 \%$ in 2015 to $23.9 \%$ by 2016. By $2016,56 \%$ of stunting children live in Asia and the highest stunting prevalence in Asia is in South Asia of $34.1 \%$. About 2 out of 5 children in the world under the age of 5 with stunting live in South Asia (UNICEF et al., 2017). Despite the decrease in stunting prevalence, the decline did not provide significant benefit because the population of children under 5 years of age was disproportionately distributed (Campisi et al., 2017).

Stunting is also a nutritional problem that is found in many children in Indonesia. Indonesia ranks fifth with the highest prevalence of stunting in the world (Trihono et al., 2015). According to the pokok-pokok hasil Riset Kesehatan Dasar (Riskesdas) in 2013, the prevalence of stunting in Indonesia among children under 5 years of age in male sex often occurs at the age of 24-35 months with a prevalence of $43 \%$ and at age 12-23 months with prevalence of $41.2 \%$. Nationally, the prevalence of stunting in 2013 was $37.2 \%$ consisting of $18 \%$ very short and $19.2 \%$ short. The prevalence of stunting in Indonesia increased from $35.6 \%$ in 2010 and $36.8 \%$ in 2007 . The highest stunting prevalence was in East Nusa
Tenggara Province which was $51.7 \%$ and the lowest in Riau Islands was $26.3 \%$ (Kemenkes RI, 2013a).

Stunting affects the decline in cognitive and physical abilities and leads to poor health in children (UNICEF, 2013). Based on research conducted by Picauly and Toy in 2013 in Kupang City, stunting children generally have less learning achievement that is equal to $41.18 \%$ and each decrease of high nutritional status of body according to age (TB/U) of child equal to 1 elementary, hence achievement learn the child will fall by 0.444 . In addition, stunting also contributes to the widening of the gap that leads to intergenerational poverty and reduces $10 \%$ of total lifetime earnings (TNP2K, 2017).

According to Kementerian Desa, Pembangunan Daerah Tertinggal, dan Transmigrasi (Kemendesa PDTT) (2017), stunting is caused by multidimensional factors such as inadequate care or poor parenting, limited health services including Antenatal Care (ANC) and Postnatal Care (PNC), limited child access to quality early learning, lack of access to households or families to nutritious food, and lack of access to clean water and sanitation. In addition, economic status and the total of family members also affect the incidence of stunting (Oktarina and Sudiarti, 2013).

Research conducted in North Biboki, North Central Timor, East Nusa Tenggara (NTT) found that there is a significant relationship between history of less care pattern, diet, nutrient intake, culture, infectious diseases and the family economy with the incidence of stunting. Based on the multivariate analysis it was found that parenting is the most dominant factor affecting the stunting event in the region (Nabuasa et al., 2013).

Parenting has an important role in order to achieve optimal child growth. Parenting is an indirect cause of stunting events and if not properly implemented can be a direct cause of stunting events, meaning parenting is the dominant factor as a cause of stunting (UNICEF, 2015). According to Engle et al (1997) there are four important components 
in the parenting that plays an important role that is food, hygiene, health, and psychosocial stimulation.

Information gathered from the World Health Organization and the World Bank publication on poor parenting practices states that about $60 \%$ of children aged 0-6 months are not exclusively breastfed, and 2 out of 3 children aged 0-24 months are not getting MPASI (TNP2K, 2017). While according to a study conducted by Najahah et al (2013), children who were not exclusively breastfed had a 4.9-fold risk of stunting, as well as improperly administered MPASI can lead to a 6.3-fold risk for stunting.

The level of cleanliness in Indonesia also contributes to the incidence of stunting. About 1 out of 5 households in Indonesia still defecate open space, and 1 in 3 households do not have access to clean drinking water (TNP2K, 2017). The study says any $10 \%$ increase in open defecation will increase the stunting incidence by $0.7 \%$ (Spears et al., 2013). Stunting events will also increase in families with poor physical quality of water $(37.8 \%)$ than in families with good physical water quality (Adiyanti and Besral, 2014).

Utilization of poor health services can also contribute to stunting events. Utilization of health services in Indonesia in the form of posyandu decreased from $79 \%$ in 2007 to 64\% in 2013 and children have not received adequate access to immunization services (TNP2K, 2017). Whereas according to research by Picauly and Toy (2013), children who do not has a history of immunization is likely to have stunting with an incidence increase of 1,983 times compared with children who have a history of immunization.

Stunting is also associated with poor psychosocial stimulation. Research Renyoet et al (2013) in the coastal area Tallo Makassar City found that children who experience stunting in general have less psychosocial stimulation of $95 \%$.

Based on research conducted in the coastal area of Barombong Village, Tamalate Subdistrict, Makassar City, the relationship between mother care practice and stunting event showed a significant relationship between feeding practices, psychosocial stimulation, hygiene practices, environmental sanitation, and health service utilization with stunting incidence in children 24-59 months. Stunting children generally have less feeding practices $(82.4 \%)$, less psychosocial stimulation (100\%), less hygiene practices $(90 \%)$, less environmental sanitation $(86.2 \%)$ and less health service utilization (76.2 \%) (Rahmayana et al., 2014).

The prevalence of stunting in West Sumatera Province in 2013 was 39.2\% and ranked 17th with the highest prevalence of stunting in Indonesia (Kemenkes RI, 2013a). According to the Pemantauan Status Gizi (PSG), stunting prevalence in West Sumatera Province in 2016 is $25.6 \%$ in children under 5 years of age consisting of very short $6.7 \%$ and short $18.9 \%$, the highest prevalence of stunting is in Pasaman District is $37 \%$ and the lowest in Sawahlunto City is $7.5 \%$, while Padang City has stunting prevalence of $21.1 \%$.

Based on data of mass weighing of Padang City Health Office in February 2015, the highest prevalence of stunting was in the working area of Air Dingin Primary Health Center which was $34.6 \%$ which consisted of very short $12.1 \%$ and $22.5 \%$ short, while the lowest stunting prevalence was in the working area of Lubuk Kilangan Primary Health Center is $1 \%$ consisting of $0.3 \%$ very short and $0.7 \%$ short.

Initial surveys conducted by the researchers found that the prevalence of stunting in Air Dingin Primary Health Center based on mass data of 2017 was $28.2 \%$. Interviews of 10 respondents found that all respondents have sufficient economic level with husband status work, 8 out of 10 mothers have children as many as 2 people and 2 mothers have children as many as 3 people. Child care is generally done by mother and grandmother, most of the mothers make ANC visits 3-4 times, all mothers interviewed have children with normal birth weight, 6 out of 10 mothers do 
not give exclusive breastfeeding to their children, some mothers provide additional food on children of formula, honey, honey mixed with water, and coffee. From the interviews, it is also found that in general, mothers do not routinely bring children to posyandu, and 7 out of 10 mothers do not routinely wash their hands before feeding children.

From the above explanation, researchers interested to examine the association between mother's care practice with the incidence of stunting in children age 12-35 months in Air Dingin Primary Health Center Padang 2018.

\section{METHODS}

This research is a quantitative research with cross sectional design to 77 mothers who have children age 12-35 months who are in Air Dingin Primary Health Center Padang on April 2018-May 2018. Data collecting is done by measuring to child height and filling pattern questionnaire foster. All data were processed using SPSS by chi-square test.

\section{RESULT}

Respondents in this study were mothers who had children age 12-35 months in the Air Dingin Primary Health Center Padang which amounted to 594 people. The characteristics of respondents in this study can be seen in table 5.1 and table 5.2 as follows:

Table 3.1 Mean Distribution of Mother Characteristics of Research Subjects

\begin{tabular}{clcc}
\hline $\begin{array}{c}\text { N } \\
\text { o }\end{array}$ & Variabel & Mean \pm SD & $\begin{array}{c}\text { Minimal- } \\
\text { Max }\end{array}$ \\
\hline 1 & $\begin{array}{l}\text { Age of } \\
\text { Mother } \\
\text { (year) }\end{array}$ & $\begin{array}{c}30,13 \pm 5,21 \\
5\end{array}$ & $20-44$ \\
\hline 2 & Total of & $2,23 \pm 1,276$ & $1-7$ \\
\hline
\end{tabular}

Mother
Children
(people)

Table 3.1 shows the average age of the mother is 30 years with the average number of children is 2 people.

Table 3.2 Frequency Distribution of Mother Characteristics of Research Subjects

\begin{tabular}{|c|c|c|c|}
\hline $\begin{array}{l}\mathbf{N} \\
\mathbf{o}\end{array}$ & Variabel & $\begin{array}{c}\text { Freque } \\
\text { ncy (f) }\end{array}$ & $\begin{array}{c}\text { Perce } \\
\text { ntage } \\
(\%)\end{array}$ \\
\hline \multirow[t]{5}{*}{1} & Mother's Age & & \\
\hline & - <20 years & 0 & 0 \\
\hline & - 20-29 years & 40 & 51,9 \\
\hline & - $\quad 30-39$ years & 31 & 40,3 \\
\hline & - $\quad \geq 40$ years & 6 & 7,8 \\
\hline \multirow[t]{8}{*}{2} & Education Level & & \\
\hline & Mother & & \\
\hline & $\begin{array}{l}\text { - Never attended } \\
\text { school/Did not } \\
\text { finish primary } \\
\text { school/MI/ } \\
\text { equivalent }\end{array}$ & 1 & 1,3 \\
\hline & 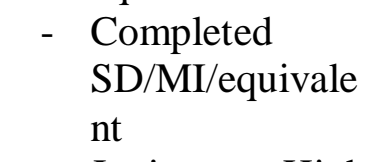 & 4 & 5,2 \\
\hline & - Junior High & 10 & 13 \\
\hline & $\begin{array}{l}\text { School/equivale } \\
\text { nt }\end{array}$ & & \\
\hline & $\begin{array}{l}\text { - High } \\
\text { school/equivale } \\
\text { nt }\end{array}$ & 48 & 62,3 \\
\hline & $\begin{array}{l}\text { - Graduated } \\
\text { PT/equivalent }\end{array}$ & 14 & 18,2 \\
\hline \multirow[t]{7}{*}{3} & Mother's job & & \\
\hline & 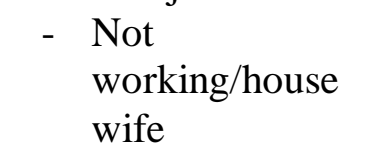 & 69 & 89,6 \\
\hline & - Farmers & 0 & 0 \\
\hline & - Labor & 0 & 0 \\
\hline & $\begin{array}{l}\text { - Civil } \\
\text { servant/private } \\
\text { employee }\end{array}$ & 3 & 3,9 \\
\hline & - Entrepreneur & 1 & 1,3 \\
\hline & - And others & 4 & 5,2 \\
\hline
\end{tabular}




\begin{tabular}{ccc}
\hline 4 Total of children & & \\
$-\quad 1-2$ children & 52 & 67.5 \\
$-\quad 3-4$ children & 20 & 26 \\
$-\geq 5$ children & 5 & 6,5 \\
\hline
\end{tabular}

Table 3.2 shows that most mothers are in the 20-29 age group and no mothers are in the $<20$ years age group. Most mothers have a high school education level or equivalent. Mayorias mother does not work or as a housewife and most mothers have children 1-2 people.

Table 3.3 Mean Distribution of Child Characteristics Subject Research

\begin{tabular}{clcc}
\hline No & Variabel & Mean \pm SD & $\begin{array}{c}\text { Minimal- } \\
\text { Max }\end{array}$ \\
\hline 1 & Child & $22,94 \pm 7,9$ & $12-35$ \\
& Age & 05 & \\
& (month) & & \\
\hline 2 & Birth & $2906,49 \pm 5$ & $1200-3900$ \\
& Weight & 40,063 & \\
& Child & & \\
& (gram) & & \\
\hline
\end{tabular}

Table 3.3 shows the average age of children is 23 months with average birth weight is 2906 grams.

Table 3.4 Frequency Distribution of Child Characteristics Subject Research

\begin{tabular}{llcc}
\hline $\begin{array}{l}\text { N } \\
\text { o }\end{array}$ & Variabel & $\begin{array}{c}\text { Freque } \\
\text { ncy (f) }\end{array}$ & $\begin{array}{c}\text { Percen } \\
\text { tage } \\
(\%)\end{array}$ \\
\hline 1 & Child Age & & \\
& $-\quad$ 12-23 year & 40 & 51,9 \\
& $-\quad 24-35$ year & 37 & 48,1 \\
\hline
\end{tabular}

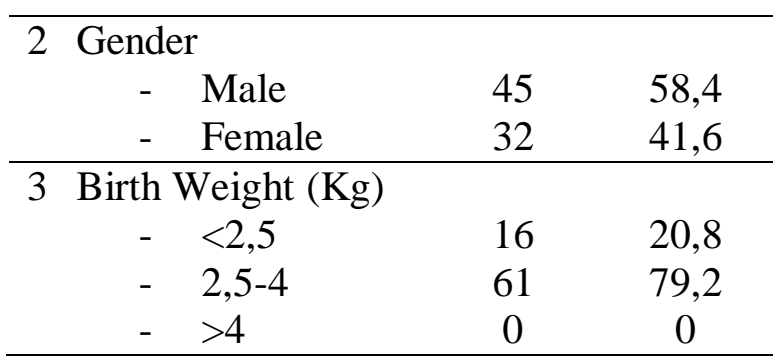

Table 3.4 shows that most children are in the 12-23 month age group with gender in general being males. The majority of children have a birth weight of $2.5-4 \mathrm{~kg}$ and no child has a birthweight $>4 \mathrm{~kg}$.

\section{Result of Univariate Analysis Child's Height}

Table 3.5 Distribution of Mean Children Height

\begin{tabular}{clcc}
\hline No & Variabel & Mean \pm SD & $\begin{array}{c}\text { Minimal- } \\
\text { Max }\end{array}$ \\
\hline 1 & $\begin{array}{l}\text { Height } \\
\text { Child } \\
\text { Body } \\
\text { (cm) }\end{array}$ & $80,96 \pm 7,613$ & $64-96$ \\
\hline
\end{tabular}

Table 3.5 shows that the average height of the children studied was $80.96 \mathrm{~cm}$.

\section{Z-Score Height Agency per Child Age}

Table 3.6 Mean Distribution of Z-Score TB / U Children

\begin{tabular}{clcc}
\hline $\mathbf{N}$ & Variabel & $\begin{array}{c}\text { Mean } \pm \text { S } \\
\text { o }\end{array}$ & $\begin{array}{c}\text { Minimal- } \\
\text { Dax }\end{array}$ \\
\hline 1 & Z-Score & - & $(-4,36)-$ \\
& TB/U & $1,3518 \pm 1$ & $(3,10)$ \\
& Children(SD) &, 61223 & \\
\hline \multicolumn{4}{c}{ Table 3.6 shows that the } \\
\end{tabular}
score of TB / U of children under study was 1.3518 SD.

\section{Frequency of Stunting}

Table 3.7 Distribution of Frequency of Stunting Incidence in Children 


\begin{tabular}{lcc}
\hline $\begin{array}{c}\text { Level } \\
\text { Stunting }\end{array}$ & $\begin{array}{c}\text { Frequency } \\
\text { (f) }\end{array}$ & $\begin{array}{c}\text { Percentage } \\
(\boldsymbol{\%})\end{array}$ \\
\hline Stunting & 36 & 46,8 \\
Normal & 41 & 53,2 \\
\hline Total & 77 & 100 \\
\hline
\end{tabular}

Table 3.7 shows that most children (53.2\%) had normal height.

Care Practice for Feeding

Table 3.8 Distribution of Frequency of Care Practice for Feeding in Children

\begin{tabular}{lcc}
\hline $\begin{array}{l}\text { Care } \\
\text { Practice } \\
\text { for }\end{array}$ & $\begin{array}{c}\text { Frequency } \\
\text { Feeding }\end{array}$ & $\begin{array}{c}\text { Percentage } \\
(\%)\end{array}$ \\
\hline Less & 32 & 41,6 \\
Good & 45 & 58,4 \\
\hline Total & 77 & 100 \\
\hline
\end{tabular}

Table 3.8 shows that most of the respondents $(58.4 \%)$ had good category care practice for feeding.

Care Practice for Hygiene

Table 3.9 Distribution of Frequency of Care Practice for Hygiene in Children

\begin{tabular}{lcc}
\hline $\begin{array}{l}\text { Care } \\
\text { Practice } \\
\text { Hygiene }\end{array}$ & $\begin{array}{c}\text { Frequency } \\
\text { (f) }\end{array}$ & $\begin{array}{c}\text { Percentage } \\
(\boldsymbol{\%})\end{array}$ \\
\hline Less & 30 & 39 \\
Good & 47 & 61 \\
\hline Total & 77 & 100 \\
\hline
\end{tabular}

Table 3.9 shows that most respondents $(61 \%)$ have good category care practice for hygiene.

\section{Care Practice for Health}

Table 3.10 Distribution of Frequency of Care Practice for Health in Children

\begin{tabular}{lcc}
\hline $\begin{array}{l}\text { Care } \\
\text { Practice for } \\
\text { Health }\end{array}$ & $\begin{array}{c}\text { Frequency } \\
\text { (f) }\end{array}$ & $\begin{array}{c}\text { Percentage } \\
(\boldsymbol{\%})\end{array}$ \\
\hline Less & 30 & 39 \\
Good & 47 & 61 \\
\hline Total & 77 & 100 \\
\hline
\end{tabular}

Table 3.10 shows that most respondents $(61 \%)$ have good category care practice for health.

Care Practice for Psychosocial Stimulation

Table 3.11 Distribution of Frequency of Care Practice for Psychosocial Stimulation in Children

\begin{tabular}{lcc}
\hline $\begin{array}{l}\text { Care } \\
\text { Practice for } \\
\text { Psychosocial }\end{array}$ & $\begin{array}{c}\text { Frequency } \\
\text { (f) }\end{array}$ & $\begin{array}{c}\text { Percentage } \\
(\%)\end{array}$ \\
Stimulation & & \\
\hline Less & 23 & 29,9 \\
Good & 54 & 70,1 \\
\hline Total & 77 & 100 \\
\hline
\end{tabular}

Table 3.11 shows that most of the respondents $(70.1 \%)$ have good category care practice for psychosocial stimulation.

\section{Results of Bivariate Analysis}

This analysis aims to determine the relationship/association between independent variables with dependent variable. The analysis used Chi-Square test with $\mathrm{p}$ value (probability), if $\mathrm{p}<0,05$ means significant relation.

Relationship Mother's Care Practice with Stunting Incidence on Research Subjects

Relationship Care Practice for Feeding with Stunting Incidence on Research Subjects

Table 3.12 Relationship of Care Practice for Feeding with Stunting Incidence 


\begin{tabular}{|c|c|c|c|c|c|c|c|}
\hline \multirow{3}{*}{$\begin{array}{l}\text { Care } \\
\text { Practi } \\
\text { ce for } \\
\text { Feedi } \\
\text { ng }\end{array}$} & \multicolumn{4}{|c|}{ Level Stunting } & \multirow{2}{*}{\multicolumn{2}{|c|}{ Total }} & \multirow{3}{*}{$\begin{array}{l}\text { p- } \\
\text { val } \\
\text { ue }\end{array}$} \\
\hline & \multicolumn{2}{|c|}{ Stunting } & \multicolumn{2}{|c|}{$\begin{array}{c}\text { Norm } \\
\text { al }\end{array}$} & & & \\
\hline & $\mathbf{f}$ & $\%$ & $\mathbf{f}$ & $\%$ & $\mathbf{f}$ & $\%$ & \\
\hline Less & 28 & $\begin{array}{c}87 \\
5\end{array}$ & 4 & $\begin{array}{c}1 \\
2, \\
5\end{array}$ & $\begin{array}{l}3 \\
2\end{array}$ & $\begin{array}{c}10 \\
0\end{array}$ & \\
\hline Good & 8 & $\begin{array}{c}17 \\
8\end{array}$ & $\begin{array}{l}3 \\
7\end{array}$ & $\begin{array}{l}8 \\
2, \\
2\end{array}$ & $\begin{array}{l}4 \\
5\end{array}$ & $\begin{array}{c}10 \\
0\end{array}$ & $\begin{array}{l}0,0 \\
00\end{array}$ \\
\hline Total & 36 & $\begin{array}{c}46, \\
8\end{array}$ & $\begin{array}{l}4 \\
1\end{array}$ & $\begin{array}{l}5 \\
3, \\
2\end{array}$ & $\begin{array}{l}7 \\
7\end{array}$ & $\begin{array}{c}10 \\
0\end{array}$ & \\
\hline
\end{tabular}

Based on Table 3.12 shows that the percentage of children who experience stunting is higher in children with less upbringing pattern compared with good eating patterns. The result of statistical test with Chi-Square test shows that there is a significant relationship between care practice for feeding and stunting incidence.

Relationship Care Practice for Hygiene with Stunting Incidence on Research Subject

Table 3.13 Relationship Care Practice for Hygiene with Stunting Incidence

\begin{tabular}{lcccc}
\hline Care & \multicolumn{2}{c}{ Level Stunting } & & p- \\
\cline { 2 - 3 } $\begin{array}{l}\text { Practi } \\
\text { ce for }\end{array}$ & Stunting & $\begin{array}{c}\text { Norm } \\
\text { Tol }\end{array}$ & & $\begin{array}{c}\text { val } \\
\text { ae }\end{array}$ \\
\hline
\end{tabular}

\begin{tabular}{lccccccc}
\hline $\begin{array}{l}\text { Hygie } \\
\text { ne }\end{array}$ & $\mathbf{f}$ & $\boldsymbol{\%}$ & $\mathbf{f}$ & $\boldsymbol{\%}$ & $\mathbf{f}$ & $\boldsymbol{\%}$ & \\
\hline Less & 28 & 93, & 2 & 6, & 3 & 10 & \\
& & 3 & & 7 & 0 & 0 & \\
Good & 8 & 17 & 3 & 8 & 4 & 10 & 0,0 \\
& & & 9 & 3 & 7 & 0 & 00 \\
Total & 36 & 46, & 4 & 5 & 7 & 10 & \\
& & 8 & 1 & 3, & 7 & 0 & \\
& & & & 2 & & & \\
\hline
\end{tabular}

Based on table 3.13 shows that the percentage of children who experience stunting is higher in children with less hygiene care pattern compared with good hygiene care pattern. The result of statistical test with Chi-Square test showed a significant relationship between care practice for hygiene with stunting incidence.

Relationship Care Practice for Health with Stunting Incidence on Research Subjects

Table 3:14 Relationship Care Practice for Health with Stunting Incidence

\begin{tabular}{|c|c|c|c|c|c|c|c|}
\hline \multirow{3}{*}{$\begin{array}{l}\text { Care } \\
\text { Practi } \\
\text { ce for } \\
\text { Healt } \\
\text { h } \\
\end{array}$} & \multicolumn{4}{|c|}{ Level Stunting } & \multirow{2}{*}{\multicolumn{2}{|c|}{ Total }} & \multirow{3}{*}{$\begin{array}{l}\text { p- } \\
\text { val } \\
\text { ue }\end{array}$} \\
\hline & \multicolumn{2}{|c|}{ Stunting } & \multicolumn{2}{|c|}{$\begin{array}{c}\text { Norm } \\
\text { al }\end{array}$} & & & \\
\hline & $\mathbf{f}$ & $\%$ & $\mathbf{f}$ & $\%$ & $\mathbf{f}$ & $\%$ & \\
\hline Less & 22 & $\begin{array}{c}73, \\
3\end{array}$ & 8 & $\begin{array}{l}2 \\
6, \\
7\end{array}$ & $\begin{array}{l}3 \\
0\end{array}$ & $\begin{array}{c}10 \\
0\end{array}$ & \\
\hline Good & 14 & $\begin{array}{c}29, \\
8\end{array}$ & $\begin{array}{l}3 \\
3\end{array}$ & $\begin{array}{l}7 \\
0, \\
2\end{array}$ & $\begin{array}{l}4 \\
7\end{array}$ & $\begin{array}{c}10 \\
0\end{array}$ & $\begin{array}{c}0,0 \\
00\end{array}$ \\
\hline Total & 36 & $\begin{array}{c}46, \\
8\end{array}$ & $\begin{array}{l}4 \\
1\end{array}$ & $\begin{array}{l}5 \\
3, \\
2\end{array}$ & $\begin{array}{l}7 \\
7\end{array}$ & $\begin{array}{c}10 \\
0\end{array}$ & \\
\hline
\end{tabular}

Based on Table 3.14 shows that the percentage of children who experience stunting is higher in children with less health care pattern compared with good health care pattern. Chi-Square test results showed a significant relationship between care practice for health with stunting incidence. 
Relationship Care Practice for Psychosocial Stimulation with Stunting Incidence on Research Subject

Table 3.15 Relationship Care Practice for Psychosocial Stimulation with Stunting Incidence

\begin{tabular}{|c|c|c|c|c|c|c|c|}
\hline \multirow{3}{*}{$\begin{array}{l}\text { Care } \\
\text { Practi } \\
\text { ce for } \\
\text { Psych } \\
\text { osocia } \\
\text { I } \\
\text { Stimu } \\
\text { lation }\end{array}$} & \multicolumn{4}{|c|}{ Level Stunting } & \multirow{2}{*}{\multicolumn{2}{|c|}{ Total }} & \multirow[b]{3}{*}{$\begin{array}{c}\text { p- } \\
\text { valu } \\
\text { e }\end{array}$} \\
\hline & \multicolumn{2}{|c|}{$\begin{array}{c}\text { Stuntin } \\
\text { g }\end{array}$} & \multicolumn{2}{|c|}{$\begin{array}{l}\text { Norm } \\
\text { al }\end{array}$} & & & \\
\hline & f & $\%$ & $\bar{f}$ & $\%$ & $\mathbf{f}$ & $\%$ & \\
\hline Less & 22 & $\begin{array}{l}9 \\
5, \\
7\end{array}$ & 1 & $\begin{array}{l}4, \\
3\end{array}$ & $\begin{array}{l}2 \\
3\end{array}$ & $\begin{array}{c}10 \\
0\end{array}$ & \\
\hline Good & 14 & $\begin{array}{l}2 \\
5, \\
9\end{array}$ & $\begin{array}{l}4 \\
0\end{array}$ & $\begin{array}{l}7 \\
4, \\
1\end{array}$ & $\begin{array}{l}5 \\
4\end{array}$ & $\begin{array}{c}10 \\
0\end{array}$ & $\begin{array}{c}0,00 \\
0\end{array}$ \\
\hline Total & 36 & $\begin{array}{l}4 \\
6, \\
8\end{array}$ & $\begin{array}{l}4 \\
1\end{array}$ & $\begin{array}{l}5 \\
3, \\
2\end{array}$ & $\begin{array}{l}7 \\
7\end{array}$ & $\begin{array}{c}10 \\
0\end{array}$ & \\
\hline
\end{tabular}

Based on Table 3.15 shows that the percentage of children who experience stunting is higher in children with less psychosocial stimulation parenting pattern compared with good psychosocial stimulation pattern. The results of statistical test with Chi-Square test showed a significant relationship between care practice for psychosocial stimulation with stunting incidence.

Primary Health Center Padang 2018 is $46.8 \%$ and the percentage of children who have a normal height of $53.2 \%$. This result is higher than the percentage of stunting globally in 2016 which is $22.9 \%$ and

\section{DISCUSSION}

\section{Stunting incidents in Children}

The percentage of stunting incidence in children age 12-35 months in Air Dingin practices $(82.4 \%)$, less psychosocial stimulation (100\%), less hygiene practice (90 $\%)$, less environmental sanitation $(86.2 \%)$ nationally in the year 2013 which is $37.2 \%$ and higher than the percentage of stunting in Padang City in 2016 that is equal to $21.1 \%$ (UNICEF et al., 2017; Kemenkes RI, 2013a; Direktorat Gizi Masyarakat, 2017). This is likely due to the wider coverage of data collection in stunting survey globally and covering all regions of the world, as well as the breadth of data collection in Riskesdas survey (2013) and Pemantauan Status Gizi in 2016 in Padang City.

The results of this study were lower than the percentage of stunting found in East Nusa Tenggara Province of $51.7 \%$ (Kemenkes RI, 2013a) and lower when compared with research conducted by Rahmayana et al (2014) in the coastal area of Barombong Village, Tamalate Subdistrict, Makassar City found stunting percentage of $54.8 \%$, and lower compared to research conducted by Renyoet et al (2013) in mothers with children aged 6-23 months in coastal area Tallo District of Makassar City. In Renyoet et al's research, most of the mothers had stunting children with $54 \%$ stunting category, this is because there is still a mother or caregiver who is less intensive and less attention to the practice of care for their children.

The high number of stunting events in this study can be caused by the presence of mothers who provide parenting practices in the form of parenting with less categories to children. Based on research conducted in the coastal area of Barombong, Subdistrict Tamalate of Makassar City showed that in general, stunting children have less care pattern with less eating

and less health service utilization (76.2\%) (Rahmayana et al., 2014).

Based on interviews, some mothers are still less attention to the growth and development of children. Some mothers do not yet have an understanding of how to provide appropriate stimulation to the child's age. Some mothers do not provide games that can support the growth and development 
of children. Some mothers choose not to immunize or not come to posyandu for family trust reasons.

The observational results of the researchers also found that some respondents live in less healthy environments and affect family hygiene patterns. Posyandu Beringin 17 is one of the posyandu located in the area where garbage dumps are and so are some other posyandu still in less clean environment. According to Azwar (1988), the environment is less clean and less healthy life behavior will cause a person susceptible to disease and affect the nutritional status and quality of human resources. The location of the respondent's residence is also quite far from the center of Padang City. According to Salimar et al (2013), it was found that stunting children were more rural $(41.7 \%)$ than in urban areas $(29.3 \%)$.

The discovery of stunting in the study area may also be due to a history of malnutrition experienced by children in the past, a history of childbirth with low birth weight and follow-up, followed by less maternal care. Studies in Libya say that the history of malnutrition, especially low birthweight, affects the incidence of stunting in children aged 1-2 years (Taguri et al., 2009). This is due to the high influence of birth weight on stunting event at the age of 6 months early, then decreased until the age of 24 months. If in the first 6 months the baby can pursue growth, it is likely that the baby can grow normally (Adair and Guilkey, 1997).

According to WHO (2010), public health problems are considered low if the prevalence of stunting $<20 \%$, considered moderate when the prevalence of stunting is $20-29 \%$, is considered high if the stunting prevalence is $30-39 \%$ and is considered very high if stunting prevalence $\geq 40 \%$. Based on the research results in Air Dingin Primary Health Center Padang 2018, the prevalence of stunting found to be included in the public health problem category is very high.

\section{Mother's Care Practice Care Practice for Feeding}

The results showed that care practice for feeding mostly in the good category that is equal to $58.4 \%$ while in the category of less that is equal to $41.6 \%$. The results of this study are in line with the research conducted by Rahmayana et al (2014) in the coastal area of Barombong, Tamalate Sub-District, Makassar City, found that the practice of feeding the mother to the most children in the good category is $72.6 \%$ while $27.4 \%$ less category. The results of this study are also in line with the research conducted by Verdianawati et al (2014) in the work area of Walantakan Primary Health Center of Minahasa Regency which found that the feeding practices given to the children in general are in good category that is $98.8 \%$ while in the category less only $1.2 \%$.

This can be due to the fact that the majority of mothers, $89.6 \%$ are housewives or unemployed, so that mothers have more time to increase their attention and support in feeding practices to children. Mothers who work less can monitor the pattern and feeding time of the child and the attitude of the mother who chooses to let alone if the child does not spend the food (Proboningrum and Khomsan, 2016).

In addition, most mothers (67.5\%) have children of 1-2 children, so the chances of children are greater in obtaining good feeding practices. According Suhardjo (1989), the large number of family members determine the fulfillment of food needs. Families who have a large number of members will try to divide the limited food so that the food consumed is not in accordance with the needs of each family member.

This can also be caused by the level of education of mothers who are good enough that the majority come from high school graduates/equivalent $62.3 \%$ and graduate of PT/equal 18.2\%. According Suhardjo (2003), the level of maternal education determines whether or not a mother is easy to absorb and understand the nutritional knowledge she gained. Education is needed so that a person, especially mothers, is more responsive to 
nutritional problems within the family and is expected to take appropriate action as soon as possible. One of the causes of nutritional disorders is the lack of nutritional knowledge and the ability of a person to apply information about nutrition in everyday life. The level of mother's nutritional knowledge influences attitudes and behaviors in choosing foodstuffs, which further affects the family's nutritional status.

\section{Care Practice for Hygiene}

The results showed that care practice for hygiene mostly located in the good category that is $61 \%$ while in the category less only by $39 \%$. The results of this study are in line with the research conducted by Rahmayana et al (2014) in the coastal area of Barombong, Tamalate Sub-District, Makassar City, found that the pattern of hygiene care or hygiene practice given by mother to the child is mostly in the good category that is $67,7 \%$ the less category is $32.3 \%$. The results of this study are also in line with research conducted by Verdianawati et al (2014) in the work area of Walantakan Primary Health Center, Kabupaten Minahasa which found that the practice of hygiene and environmental sanitation given to children in general is in good category that is $98.8 \%$ while in the category less than $1.2 \%$.

This can be caused by the education level of mothers who are good enough that the majority come from high school graduate/equal $62.3 \%$ and graduate of PT/equal 18.2\%. According Sulastri (2012), maternal education will affect the health and welfare of children so that this will affect the nutritional status of children. Mothers with a good level of education will more easily absorb information when compared with the mother who is less or not educated. This can affect the attitude and behavior of the mother in giving hygiene practice to her child.

Mothers with a high level of education will have a broader knowledge of child-care practices and be able to maintain and maintain a clean environment (Taguri et al.,
2009). Parents, especially mothers who get higher education can perform better child care than parents with low education. Parents with lower education (Ikeda et al., 2013).

This may also be due to the fact that most mothers, $89.6 \%$ are housewives or unemployed, so that mothers have more opportunities to increase their attention and support in child hygiene practices.

\section{Care Practice for Health}

The results showed that care practice for health mostly in the good category that is $61 \%$ while in the category less only by $39 \%$. The results of this study are in line with the research conducted by Renyoet et al (2013) in the coastal area of Tallo Makassar City which found that the pattern of health care or the utilization of maternal health services to support the health status of the children mostly in the category of $81.3 \%$ category less that is $18,7 \%$.

This can be caused by the education level of mothers who are good enough that the majority come from high school graduate/equal $62.3 \%$ and graduate of PT/equal 18.2\%. According to Bahar (2002), maternal care for children requires knowledge to implement them. Green theory in Notoatmodjo (2012) mentions a person's knowledge can be a factor that supports or becomes a barrier to good health behavior.

This can also be because most mothers, $89.6 \%$ are housewives or unemployed, so the mothers have more time to increase their attention and support in child health practices. In-depth interviews found that unemployed mothers had more opportunities to take their children to posyandu compared with working mothers.

\section{Care Practice for Psychosocial Stimulation}

The results showed that care practice for psychosocial stimulation mostly located in the good category that is equal to $70.1 \%$ while in the category less only by $29.9 \%$. 
The results of this study are in line with the research conducted by Renyoet et al (2013) in the coastal area of Tallo district of Makassar City which found that the pattern of psychosocial stimulation is mostly in the sufficient category of $86.7 \%$ compared to the less category ie $13.3 \%$. The results of this study are also in line with the research conducted by Verdianawati et al (2014) in the work area of Walantakan Primary Health Center of Minahasa Regency found that the pattern of psychosocial stimulation in general is in good category that is $97.6 \%$ while in the category less only $2,4 \%$.

This can be caused by the education level of mothers who are good enough that the majority come from high school graduate/equal $62.3 \%$ and graduate of PT/equal $18.2 \%$. Research by the Ministry of National Education and the World Bank (2012), shows that parental education and home care practices can lead to better child development. According to Helmy et al (2013), all the potential possessed by children can be stimulated by parents, but before stimulation, parents need supplies of knowledge about stimulation in order to support the growth and development of children. The higher a mother's education the better the quality of psychosocial stimulation given to the child (Proboningrum and Khomsan, 2016).

This can also be caused by the majority of mothers, $89.6 \%$ are housewives or unemployed so that mothers have more time to raise their attention and support in psychosocial stimulation parenting to children. This is in accordance with research conducted by Proboningrum and Khomsan (2016) which found that the average score of psychosocial stimulation of children in the group of mothers did not work that is equal to 41,34 higher than the working mother group that is only equal to 38,55 . Mothers who do not work have more time to pay attention to stimuli given to children.

The results of in-depth interviews found that unemployed mothers had more opportunities to pay attention to children's play patterns and more interaction in daily life with children. Mothers who do not work also have more time to supervise children in play so that children have more opportunities to play around in the environment.

\section{The Association Between Mother's Care Practices With Stunting Incident In Children Age 12-35 Months In Air Dingin Primary Health Center Padang 2018}

\section{Relationship of Care Practice for Feeding with Stunting Incidence in Children 12-35 Months}

The result of statistical test using ChiSquare test shows the value $\mathrm{p}=0,000$ ( $\mathrm{p}$ $<0,05)$. Based on these results it can be concluded that there is a significant relationship between the care practice for feeding with the incidence of stunting in children aged 12-35 months in Air Dingin Primary Health Center Padang 2018. The results of this study in line with research conducted by Noci (2016) in Nanggalo Subdistrict of Padang City showed that there was a significant correlation between feeding pattern with stunting incidence in newly enrolled children where $\mathrm{p}$ value $<0,05$ ( $\mathrm{p}=$ $0,004)$.

The results of this study are also supported by several theories about the relationship between eating patterns or eating practices with stunting events in children. Breastfeeding and MPASI is one of the important things in the practice of child care. Breastfed children will be healthier and achieve optimal growth compared to formula-fed children. Children who are not breastfed have risks for illness and can inhibit growth and even cause death and disability (Moehji, 2008).

This is in line with the WHO (2003) recommendation on global strategy for infant and young child feeding. There are four important things to do for optimal child development: breastfeeding the baby immediately within 30 minutes of birth, giving exclusive breastfeeding to infants until the infant is six months old, provides 
MPASI from infants aged six months to 24 months and continues breastfeeding until the child is 24 months or older. Lack of breastfeeding and early delivery of MPASI may increase the risk of stunting events especially early in life (Adair and Guilkey, 1997).

The results of research conducted by researchers on the pattern of mother feeding given to the child found that from 77 respondents only 43 mothers who give exclusive breastfeeding to their children and only 37 mothers who feed children 3 times a day. According to Uliyanti et al (2017), the adequacy or absence of nutritional intake will provide changes in nutritional status. The better one's nutritional intake the smaller the stunting event.

Feeding practices in infants are an important foundation in the growth process. Around the world around $30 \%$ of children under the age of five with stunting are a consequence of poor feeding practices and recurrent infections (WHO, 2017). This is supported by the opinion of Hutagalung (2012) in his research on the factors that affect the nutritional status of children under five years old, that the role of family, especially mothers, has a very important role related to the pattern of feeding in the care of children, such as feeding and feeding their children. Appropriate grooming pattern of feeding will lead to better nutritional status of children, because with proper feeding patterns children will get a good intake of nutrients in accordance with the level of needs that are useful for growth and development.

So it can be said that mothers who pay attention to the practice of eating children will have a positive effect on the state of nutritional status of children, which is illustrated in this study that children with normal height most $(82.2 \%)$ have good eating patterns.

\section{Relationship of Care Practice for Hygiene with Stunting Incidence in Children 12-35 Months}

The result of statistical test using ChiSquare test shows the value $\mathrm{p}=0,000$ ( $\mathrm{p}$ $<0,05)$. Based on these results, it can be concluded that there is a significant relationship between care practice for hygiene with stunting incidence in children aged 12-35 months in Air Dingin Primary Helath Center Padang 2018. The results of this study are in line with research conducted by Rahmayana et al (2014) in coastal area of Barombong, Tamalate Subdistrict of Makassar City showed that there is a significant relationship between hygiene care pattern with stunting incidence in children aged 24-59 months where the value of $p$ $<0,05(\mathrm{p}=0,000)$.

Research conducted by Aditianti (2010) on the determinants of stunting in Indonesia also supports the results of this study, with the results of research that hygiene practice is a factor that significantly influence the incidence of stunting in children aged 24-59 months in Indonesia. Mothers who do the habit of washing hands before feeding the child, before preparing food, after defecation and after holding the animals in general have children with normal height.

The results of this study are also in line with research conducted by Van der Hoek (2002), children from families with clean water facilities and latrine ownership have lower rates of diarrhea and stunting than children from families with no clean water and ownership facilities toilet.

Poor sanitation and hygiene practices can cause a person to be exposed to various infectious diseases that cause nutrients difficult to absorb by the body (Charles and Schmidt, 2014). Cleanliness of body, food and environment plays an important role in maintaining health and prevent disease. One focus of the WHO campaign to reduce the incidence of infectious diseases such as diarrhea is to get used to wash hands with soap before meals and after defecation. Hand washing with clean water and soap can reduce the incidence of diarrhea by $42-47 \%$ (Kullu et al., 2018). 
Handwashing practices each doing food-related or breast-feeding jobs, drinking cooked water, heating food from outside the home before giving it to children, preventing food from flies and other contaminants, and using family latrines can prevent diarrhea in children (Ayu, 2008).

The quality of the environment, especially the availability of clean water, sanitation facilities, healthy living behaviors such as hand-washing with soap, toilet bowel movements, no smoking, indoor air circulation and so on need attention, this is necessary because of good personal hygiene and environment can reduce the risk of infectious diseases that may affect a child's growth (Kullu et al., 2018).

So it can be said that the mother who pay attention to the pattern of hygiene applied to the child will have a positive effect on the nutritional status of children, which is described in this study that children with normal height most (83\%) have good hygiene care pattern.

\section{Relationship of Care Practice for Health with Stunting Incidence in Children 12-35 Months}

The result of statistical test using ChiSquare test shows the value $\mathrm{p}=0,000$ ( $\mathrm{p}$ $<0,05)$. Based on these results it can be concluded that there is a significant relationship between care practice for health with the incidence of stunting in children aged 12-35 months in Air Dingin Primary Health Center Padang 2018. The results of this study are in line with the research conducted by Renyoet et al (2013) in the coastal area of Tallo Makassar City showing that there is a significant relationship between the pattern of health care with the incidence of stunting in children aged 6-23 months where the $\mathrm{p}$ value $<0.05(\mathrm{p}=0.006)$. The results of this study also supported by the theory and some other research results that say that the pattern of health care affects the growth and development of children.

Child health status is one aspect of parenting that can affect the nutritional status of children. Child health status can be assessed whether good or bad is by considering the child's nutritional status, completeness of immunization, child's personal hygiene and the environment where the child is located, and the mother's efforts in treating and seeking treatment of children when the child is sick. Children who are often sick can inhibit or interfere with the growth process (Zeitlin et al., 1990). The pattern of health care is the practice of parenting or family care in servicing the health needs of children under five that is done repeatedly so it becomes a habit (Rohimah et al., 2015).

The results of observations and interviews conducted by the researchers found that most mothers who have stunting children choose not to come to posyandu for some reason and not bring their children to health care facilities if his son is sick. Most mothers choose to treat their own children at home by means of traditional medicine and a small number of mothers bring their children to the shaman.

According to Hidayat et al (2009), the households using health services in posyandu have more good nutrition status based on TB/U compared to the under-five households who never go to posyandu. An area where there is a difficult community to gain access and contact with health services that lead to low immunization coverage, the children are more susceptible to malnutrition that may affect the child's growth (Kullu et al., 2018).

So it can be said that the mother who consider the condition or health status of children will have a positive effect on the state of nutritional status of children, where described in this study that children with normal height most (70.2\%) have good health care pattern.

\section{Relationship of Care Practice for Psychosocial Stimulation with Stunting Incidence in Children 12-35 Months}

The result of statistical test using ChiSquare test shows the value $\mathrm{p}=0,000$ ( $\mathrm{p}$ $<0,05)$. Based on these results it can be 
concluded that there is a significant relationship between care practice for psychosocial stimulation with the incidence of stunting in children aged 12-35 months in Air Dingin Primary Health Center Padang 2018. The results of this study in line with research conducted by Afryanti (2015) in the Nanggalo Subdistrict Padang City showing that there is a significant correlation between psychosocial stimulation pattern and the incidence of stunting in children aged 6-23 months where the $\mathrm{p}$ value $<0,05(\mathrm{p}=0,002)$. The results of this study are not in accordance with the research conducted by Kullu et al (2018) in Wawatu Village, North Moramo Sub-district of South Konawe Regency, showing no significant relationship between psychosocial stimulation and stunting incidence in children aged 24-59 months where the value $\mathrm{p}=0.280$.

The results of this study are supported by Zeitlin et al (1990) which states that poor psychosocial conditions can negatively affect the use of nutrients in the body, otherwise a good psychosocial condition will stimulate growth hormone while stimulating children to train their developmental organs. A good psychosocial stimulation pattern is closely related to good nutrition and health care so that indirectly have a positive effect on nutritional status, growth and development of children (Engle et al., 1997). Ability and growth of children should be stimulated by parents so that children can grow and develop optimally and according to age.

The results of the in-depth observation found that mothers with stunting children generally did not have a variety of game tools that could support the development of children, even in a household with stunting children, the mother did not provide any game tools to play the child. Most stunting children play more often in the yard or inside the house by taking advantage of the surrounding conditions.

So it can be said that the mother who pay attention to child psychosocial stimulation pattern will have a positive effect to the state of nutritional status of children, which is described in this study that children with normal height most (74.1\%) have good psychosocial stimulation pattern.

\section{CONCLUSION}

The distribution of stunting frequencies in the working area of Padang Puskesmas Padang in 2018 includes a very high category of public health problems. The frequency distribution of feeding pattern, hygiene care pattern, health care pattern and psychosocial stimulation parenting pattern for children age 12-35 months in the working area of Air Dingin Primary Health Center Padang in 2018 are mostly good category. The better the pattern of upbringing, the pattern of hygiene, the pattern of health care and the psychosocial stimulation pattern that the mother gives to the child, the lower the occurrence of stunting in children. It is expected that mothers, especially pregnant women and new mothers give birth in order to pay attention to children's food intake, hygiene practices, health care and provide psychosocial stimulation according to the age of the child so that children can achieve optimal growth and can prevent the risk of stunting in children. 


\section{REFERENCES}

Adair, L.S., dan D.K. Guilkey. Age-Specific Determinants of Stunting in Filipino Children. American Society for Nutritional Sciences : 314-320.

Aditianti. 2010. Faktor Determinan Stunting Pada Anak Usia 24-59 Bulan di Indonesia. IPB. Tesis.

Adiyanti, M., dan Besral. 2014. Pola Asuh Gizi, Sanitasi Lingkungan, dan Pemanfaatan Posyandu dengan kejadian Stunting pada Baduta di Indonesia (Analisis Data Riskesdas Tahun 2010). Universitas Indonesia. Skripsi.

Ayu, S.D. 2008. Pengaruh Program Pendampingan Gizi terhadap Pola Asuh, Kejadian Infeksi dan Status Gizi Balita Kurang Energi Protein. Univeristas Diponegoro. Tesis.

Azwar, A. 1998. Pengantar Epidemiologi. Bina Aksara Ripa. Jakarta.

Bahar, B. 2002. Pengaruh Pengasuhan terhadap Pertumbuhan Anak di Kabupaten Barru Propinsi Sulawesi Selatan. Program Pascasarjana Universitas Airlangga. Desertasi.

Campisi, S.C., A.M. Cherian., dan Z.A. Bhutta. 2017. World Perspective on the Epidemiology of Stunting between 1990 and $2015 . \quad$ [online]. Tersedia: https://www.ncbi.nlm.nih.gov/pubmed/28285312. [4 Februari 2018].

Charles, W., dan Schmidt. 2014. Beyond Malnutrition, The Role of Sanitation in Stunted Growth. Environmental Health Perpevtives, 122(11): 298-303.

Direktorat Gizi Masyarakat. 2017. Hasil Pemantauan Status Gizi (PSG) dan Penjelasannya Tahun 2016. Kemenkes RI. Jakarta.

Penimbangan Massal Dinas Kesehatan Kota Padang Februari 2015. Dinas Kesehatan Kota Padang. Padang.

Engle, P.L., P. Menon., dan L. Haddad. 1997. Care and Nutrition: Concepts and Measurement. [online].

Tersedia: http://digitalcommons.calpoly.edu/cgi/viewcontent.cgi? article $=1001 \&$ context $=$ psycd_f ac. [4 Februari 2018].

Helmy, B.K., A.Y. Ismanto., dan A. Babakal. Hubungan Tingkat Pengetahuan Orangtua tentang Stimulasi Dini dengan Perkembangan Anak Usia 4-5 Tahun di Desa Ranoketang Atas. Ejournal keperawatan, Vol 1 (1): 1-8.

Hidayat, T.S., Hermina., dan N. Fuada. 2009. Pemanfaatan Pelayanan Kesehatan Kaitannya dengan Status Gizi dan Morbiditas Anak. Laporan Analisis Lanjut Data Riskesdas. Badan Litbangkes. Jakarta.

Hutagalung, H. 2012. Faktor-Faktor yang Mempengaruhi Status Gizi Balita (12-59 Bulan) di Desa Bojonggede Kabupaten Bogor Tahun 2012. Universitas Indonesia. Skripsi. 
Kemenkes RI. 2013a. Riset Kesehatan Dasar (RISKESDAS) 2013. Badan Penelitian dan Pengembangan Kesehatan Kementerian Kesehatan RI. Jakarta.

Kemenkes RI. 2013b. Pokok-Pokok Hasil RISKESDAS INDONESIA 2013. Badan Penelitian dan Pengembangan Kesehatan Kementerian Kesehatan RI. Jakarta.

Kemendesa PDTT. 2017. Buku Saku Desa dalam Penanganan Stunting. Jakarta: Kementerian Desa, Pembangunan Daerah Tertinggal dan Transmigrasi.

Kementerian Pendidikan Nasional Republik Indonesia dan Bank Dunia. 2012. Laporan Pendidikan dan Pengembangan Anak Usia Dini di Indonesia: Landasan Kokoh, Hari Esok Cerah. Kementrian Pendidikan Nasional Republik Indonesia. Jakarta.

Kullu, V.M., Yasnani., dan H. Lestari. 2018. Faktor-Faktor yang Berhubungan dengan Kejadian Stunting pada Balita Usia 24-59 Bulan di Desa Wawatu Kecamatan Moramo Utara Kabupaten Konawe Selatan Tahun 2017. Jurnal Ilmiah Mahasiswa Kesehatan Masyarakat, Vol. 3 (2): 1-11.

Nabuasa, C.D., M. Juffrie., dan E. Huriyati. 2013. Riwayat Pola Asuh, Pola Makan, Asupan Zat Gizi Berhubungan dengan Stunting pada Anak 24-59 Bulan di Biboki Utara, Timor Tengah Utara, Nusa Tenggara Timur. Jurnal Gizi dan Dietik Indonesia, 1(3):31-43.

Najahah, I., K.T. Adhi., dan GN.I. Pinatih. 2013. Faktor Risiko Balita Stunting Usia 12-36 Bulan di Puskesmas Dasan Agung, Mataram, Provinsi Nusa Tenggara Barat. [online]. Tersedia: https://ojs.unud.ac.id/index.php/phpma/article/view/7869. [9 Februari 2018].

Noci, R.E. 2016. Hubungan Pola Asuh Ibu terhadap Kejadian Stunting pada Anak Baru Masuk Sekolah Dasar di Kecamatan Nanggalo Kota Padang. Universitas Andalas. Skripsi.

Notoatmodjo, S. 2012. Promosi kesehatan dan Perilaku Kesehatan. PT. Rineka Cipta. Jakarta.

Oktarina, Z., dan T. Sudiarti. 2013. Faktor Risiko Stunting pada Balita (24-59 Bulan) di Sumatera. Jurnal Gizi dan Pangan, November 2013, 8(3): 175-180.

Picauly, I dan S.M. Toy. 2013. Analisis Determinan dan Pengaruh Stunting terhadap Prestasi Belajar Anak Sekolah di Kupang dan Sumba Timur, NTT. Jurnal Gizi dan Pangan, Maret 2013, 8(1): 55-62.

Proboningrum, A.R., dan A. Khomsan. 2016. Pola Asuh, Stimulasi Psikososial, dan Status Gizi Balita di Kabupaten Kudus. Jurnal Nutrisia, Vol. 18 (1): 7-10.

Rahmayana, I.A. Ibrahim., dan D.S. Damayati. 2014. Hubungan Pola Asuh Ibu dengan Kejadian Stunting Anak Usia 24-59 Bulan di Posyandu Asoka II Wilayah Pesisir Kelurahan Barombong Kecamatan Tamalate Kota Makassar Tahun 2014. Public Health Science Journal, (VI)2: 424-436.

Renyoet, B.S., V. Hadju., dan St.N. Rochimiwati. 2013. Hubungan Pola Asuh Dengan Kejadian Stunting Anak Usia 6-23 Bulan Di Wilayah Pesisir Kecamatan Tallo Kota Makassar. Universitas Hasanuddin Makassar. Skripsi. 
Rohimah, E., L. Kustiyah., dan N. Hernawati. 2015. Pola Konsumsi, Status Kesehatan dan Hubungannya dengan Status Gizi dan Perkembangan Balita. J. Gizi Pangan, 10(2): 93100 .

Salimar, D. Kartono., N. Fuada., dan B. Setyawati. 2013. Stunting Anak Usia Sekolah di Indonesia Menurut Karakteristik Keluarga. Penelitian Gizi dan Makanan, vol. 36 (2): 121-126.

Spears, D., A. Ghosh., dan O. Cumming. 2013. Open Defecation and Childhood Stunting in India: nn Ecological Analysis of New Data from 112 Districts. Plos One, september 2013, volume 8, issue 9.

Suhardjo. 1989. Sosio Budaya Gizi. Departemen Pendidikan dan Kebudayaan, Dirjen Pendidikan Tinggi, Pusat Antar Universitas Pangan dan Gizi. IPB.

Suhardjo. 2003. Berbagai Cara Pendidikan Gizi. Bumi Aksara. Jakarta.

Sulastri, D. 2012. Faktor Determinan Kejadian Stunting pada Anak Usia Sekolah di Kecamatan Lubuk Kilangan Kota Padang. Majalah Kedokteran Andalas, 36(1):41.

Taguri, A.E., I. Betilmal., S.M. Mahmud., A.M, Ahmed., O. Goulet., P. Galan., dan S. Hercberg. 2009. Risk Factor for Stunting Among Under-Five in Libya. Public Health Nutrition, 12(8): 1141-1149.

TNP2K. 2017. 100 Kabupaten/Kota Prioritas Untuk Intervensi Anak Kerdil (Stunting) Ringkasan. Sekretariat Wakil Presiden RI. Jakarta.

Uliyanti, U., D.G. Tamtomo., dan S. Anantanyu. Faktor yang Berhubungan dengan Kejadian Stunting pada Balita Usia 24-59 Bulan. Jurnal Vokasi Kesehatan 3(2): 67-77.

UNICEF. 2013. The State of the World's Children 2013. [online]. Tersedia: https://www.unicef.org/sowc2013/files/SWCR2013_ENG_Lo_res_24_Apr_2013.pdf. [4 Februari 2018].

UNICEF. 2015. Unicef's Approach to Scaling Up Nutrition for Mothers and Their Children. [online]. Tersedia: $h$ t $t$ p $s$ : / / $w w w$. unicef.org/nutrition/files/Unicef_Nutrition_Strategy.pdf. [1 Maret 2018].

UNICEF., WHO., dan World Bank Group. 2017. Levels and Trends In Child Malnutrition. [online]. Tersedia: https://data.unicef.org/wp-content/uploads/2017/05/JME-2017brochure-1.pdf. [4 Februari 2018].

Van der Hoek, W., S.G. Feenstra., dan F. Konradsen. Availability of Irrigation Water for Domestic Use in Pakistan: Its Impact on Prevalence of Diarrhoea and Nutritional Status of Children. J Health Popul Nutr, 20(1): 77-84.

Verdianawati, C.P. Astuti., N.H. Kapantow., dan B.T. Ratag. 2014. Hubungan Antara Pola Asuh Ibu dengan Status Gizi Anak Usia 1-3 Tahun di Wilayah Kerja Puskesmas Walantakan Kabupaten Minahasa. Universitas Sam Ratulangi Manado. [online]. Tersedia: 
http://fkm.unsrat.ac.id/wp-content/uploads/2015/02/JURNAL-PUBLIKASI-VCPA101511296-1.pdf. [17 Mei 2018].

WHO. 2003. Global strategy for infant and young child feeding. [online]. Tersedia:http://www.who.int/nutrition/publications/infantfeeding/9241562218/en/.pdf. [17 Mei 2018].

WHO. 2010. Nutrition Landscape Information System (NLIS) : Country Profile Indicators Interpretation Guide. [online]. Tersedia: http://www.who.int/nutrition/nlis_interpretationguide_isbn9789241599955/en/. Februari 2018].

WHO. 2014. Global Nutrition Targets 2025: Stunting Policy Brief. [online]. http://www.who.int/nutrition/publications/globaltargets2025_policybrief_stunting/en/. [4 Februari 2018].

WHO. 2017. Global Database on Child Growth and Malnutrition. [online]. Tersedia: $h t t p: / /$ $w w w$. who. in t/nutgrowthdb/about/introduction/en/index6.html. [18 Mei 2018].

Zeitlin, M., H. Ghassemi., M. Mansour. 1990. Positive deviance in child nutrition-with emphasis on psychosocial and behavioural aspects and implications for development. Tokyo: The United Nations University. [online]. Tersedia: ht t $p s: / / s 3$. a m a zo n a w s c o m /academia.edu.documents/30201659/posdev.pdf. [18 Mei 2018]. 